\title{
Risk factors associated with the occurrence of multiresistant Staphylococcus spp. isolated from bovine subclinical mastitis in northern Brazil
}

\section{Fatores de risco associados à ocorrência de espécies multirresistentes de Staphylococcus spp. isolados de mastite subclínica bovina na região norte do Brasil}

\author{
Lilian Bernardina Ferreira ${ }^{1 *}$; Larissa de Freitas Santiago Israel ${ }^{2}$; \\ Renata Fernandes Rabello3; Guilherme Nunes de Souza4; Rui Carlos Peruquetti5; \\ Luciana dos Santos Medeiros ${ }^{5}$
}

\section{Highlights}

Coagulase-negative Staphylococci were the most frequent.

S. chromogenes was the species with the highest incidence.

All multiresistant species showed resistance to penicillin.

Lack of water in the corral was associated with multiresistance.

\begin{abstract}
Staphylococcus bacteria are often associated with subclinical bovine mastitis. This study aimed to identify multiresistant Staphylococcus spp. associated with subclinical mastitis and the associated risk factors. Twenty-three dairy farms with a history of decrease in milk production, located in the lower Acre region, Brazil, were selected. An epidemiological questionnaire was provided in all farms. All animals were examined using the California Mastitis Test (CMT) and their milk samples were collected for bacterial culture. After isolation and identification, the disk diffusion antimicrobial susceptibility test was performed against nine classes of antimicrobials. Of the 339 cows examined using the CMT, 108 had mastitis. A total of 229 milk samples were collected from individual teats. MALDI-TOF MS found isolates belonging to eight species of
\end{abstract}

1 Master in Animal Science, Postgraduate Program in Health and Sustainable Animal Production in the Western Amazon, Universidade Federal do Acre, UFAC, Rio Branco, AC, Brazil. E-mail: lilianbernardina@hotmail.com

$2 \mathrm{PhD}$ in Animal Science, Postgraduate Program in Health and Sustainable Animal Production in the Western Amazon, UFAC, Rio Branco, AC, Brazil. E-mail: larissafreitas.vet@gmail.com

${ }^{3}$ Profa Dra, Graduate Program in Applied Microbiology and Parasitology Instituto Biomédico, Universidade Federal Fluminense, UFF, Niterói, RJ, Brazil. E-mail: rerabello@hotmail.com

${ }^{4}$ Dr., Researcher at the Empresa Brasileira de Pesquisa Agropecuária, EMBRAPA, Juiz de Fora, MG, Brazil. E-mail: guilherme.souza@embrapa.br

${ }_{5}$ Profs. Drs., Postgraduate Program in Health and Sustainable Animal Production in the Western Amazon, UFAC, Rio Branco, AC, Brazil. E-mail: rcperuquetti@yahoo.com.br; lusmedeiros@yahoo.com.br

* Author for correspondence

Received: June 30, 2021 - Approved: Dec. 21, 2021 
Staphylococcus, in 101 of these samples. S. chromogenes (58.4\%) demonstrated strongest resistance to the nine classes of antimicrobial active principles. Nineteen isolates with multidrug resistance phenotypic profile were identified. This phenotypic expression indicates wide circulation of resistant genes in this species. The presence of multidrug resistance in Staphylococcus spp. in this study was correlated with lack of water for cleaning the corral, which is a preventive factor, minimizing the transmission and persistence of pathogens in the farms.

Key words: Risk factors. Mastitis. Multidrug resistance. Staphylococcus.

\section{Resumo}

Bactérias do gênero Staphylococcus são frequentemente associadas a mastite bovina subclínica. O objetivo do presente estudo foi identificar as espécies de Staphylococcus caracterizadas fenotipicamente como multirresistentes, associadas a mastite subclínica e identificar os fatores de risco associados. Foram selecionadas 23 propriedades leiteiras com histórico de queda de produção, localizadas na região do baixo Acre, Brasil. Em todas as propriedades foram preenchido um questionário epidemiológico. Todos os animais foram submetidos ao California Mastitis Test (CMT) e amostras de leite foram coletadas para cultura bacteriana. Após isolamento e identificação, foi realizado o teste de suscetibilidade antimicrobiana por difusão de disco frente à nove classes de antimicrobianos. Ao todo, 339 vacas foram testadas pelo CMT identificando 108 animais com mastite. Foram coletadas 229 amostras de leite de tetos individuais. Destas, 101 apresentaram isolados pertencentes ao gênero Staphylococcus, distribuídas em oito espécies identificadas por MALDI-TOF. S. chromogenes $(58,4 \%)$ foi a espécie mais frequente demonstrando resistência as nove classes de princípios ativos antimicrobianos. Foram identificados 19 isolados com perfil fenotípico de multirresistência. Esta expressão fenotípica indica a ampla circulação de genes de resistência nesta espécie. A presença de multirresistência em Staphylococcus neste estudo foi correlacionada com a ausência da implementação do manejo em linha de ordenha e ausência de água no curral para limpeza, que funcionam como fatores preventivos, minimizando a transmissão e persistência dos patógenos nas propriedades.

Palavras-chave: Fatores de risco. Mastite. Multirresistência. Staphylococcus.

Bovine mastitis is an inflammatory reaction of the mammary gland (Moritz \& Moritz, 2016), usually of an infectious nature. Bacteria are the main etiological agents for bovine mastitis (Casanova et al., 2016), and it is described by several authors as one of the most important diseases of dairy herds.

Staphylococcus has been identified in several studies as one of the main pathogens that cause mastitis (Aslanta \& Demir, 2016; Casanova et al., 2016). This genus is important not only because of its ubiquitous nature, but also because of its multiresistance to antibiotics used in intervention protocols, making mastitis a disease of public health concern (Ganda, Bisinotto, Decter, \& Bicalho, 2016).

Proper management practices to prevent and treat mastitis require not only the identification of causative pathogens, but also effective antibiotics with reduced risk factors. 
Therefore, this study aimed to identify the Staphylococcus species and risk factors associated with phenotypic profile of antimicrobial multidrug resistance, in cattle with subclinical mastitis from lower Acre, Brazil. Queiroz and Souza (2021) considered Acre as a state of low milk production with an average productivity much lower than the regional as well as the national average, where the results may have a direct impact on the local production chain.

Twenty-three farms, located in the municipalities of Acre, northern Brazil, with a history of decrease in milk production were selected by non-probabilistic sampling from November 2015 to September 2018.

Cows were clinically evaluated to identify clinical mastitis and subsequently examined for subclinical mastitis using the California Mastitis Test (CMT). Milk samples from teats affected by the disease were collected individually. All collection and transport procedures were carried out in accordance with the recommendations of the National Mastitis Council [NMC] (2004). The samples were properly identified, refrigerated, and processed in laboratory.

Milk samples were plated on blood agar supplemented with 5\% defibrinated sheep blood (BioMérieux, Taquara, RJ, Brazil) and incubated under aerobic conditions at $37^{\circ} \mathrm{C}$ for 24 to 48 hours. Subsequently, the colonies that grew on the selective agar were seeded directly onto Mueller-Hinton agar. Gram-positive catalase-positive cocci were identified by MALDI-TOF MS (MALDI Biotypes 3.1, Bruker Daltonik, Bremen, Germany).

Antimicrobial susceptibility was determined using the disk diffusion method, according to the Clinical and Laboratory Standards Institute [CLSI] (2018).
Thirteen antimicrobial active principles of nine different classes were tested: penicillin $\mathrm{G}(30 \mu \mathrm{g})$, cefoxitin $(30 \mu \mathrm{g})$, ceftiofur (30 $\mu \mathrm{g})$, enrofloxacin (5 $\mu \mathrm{g})$, ciprofloxacin (5 $\mu \mathrm{g})$, gentamicin $(10 \mu \mathrm{g})$, streptomycin $(10 \mu \mathrm{g})$, clindamycin $(2 \mu \mathrm{g})$, tetracycline (30 $\mu \mathrm{g})$, erythromycin $(15 \mu \mathrm{g})$, rifampicin $(5 \mu \mathrm{g})$, chloramphenicol $(30 \mu \mathrm{g})$, and linezolid (30 $\mu \mathrm{g})$. Test $\mathrm{D}$ was performed to determine clindamycin-induced resistance (CLSI, 2018).

The following data were concurrently collected to characterize production and identify the risk factors: type of rearing (intensive or extensive), presence of electricity on the farm, storage facility (expansion tank, immersion, or freezer) and production type (family production or dairy), whether mastitic cows were segregated at the time of milking, presence of the calf with the mother during milking, type of milking (mechanical or manual), presence of water, drinking fountain, containment trunk, and paving in the corral, milking times (morning and/or afternoon), pre and post-dipping, drying of the teats after cleaning and material used to do it (paper towel or cloth), performance of the CMT and wired cup test, use of antibiotics during the collection period, whether the utensils and corral were cleaned with water and sanitizer or just water and whether they were dried or left to dry in air after milking.

The frequency distribution of the questionnaire variables, the results of the $\mathrm{CMT}$, the number of cows with subclinical mastitis, and the resistance profile according to the antimicrobials were evaluated. The association between the multidrug resistance profile with the epidemiological variables and with antimicrobials was assessed using the Chi-square test, with adjustment of Fisher's exact test (univariate analysis) for cases with 
$<5$ evaluated categories (Sampaio, 1998). We considered a significance level of $95 \%$ ( $p<$ 0.05).

The project was approved by the Ethics Committee on the Use of Animals (CEUA-UFAC) No. 23107.010416/2015-38.

In total, 339 lactating crossbred cows were evaluated in the 23 selected farms. Of these, 108 (31.8\%) were positive reagents in the CMT, originating from 229 milk samples from individual teats. Among these samples, 101 isolates belonged to eight species of Staphylococcus genus: S. chromogenes (58.4\%), S. aureus (19.8\%), S. hyicus (7.9\%), S. saprophyticus (4.9\%), S. haemolyticus (4\%), S. epidermidis (3\%), S. xylosus (1\%), and $S$. kloosii (1\%). Among these isolates, 72.3\% belonged to the group of coagulase-negative staphylococci (CNS) and $27.7 \%$ to the group of coagulase-positive staphylococci (CPS).

Unsurprisingly, the prevalence of $S$. chromogenes was high, as an earlier study also reported a higher prevalence of $S$. chromogenes (60\%) in the same region and using the same methodology (Israel, Rabello, Domingos, \& Medeiros, 2018). But these authors also reported only one $S$. aureus isolate (1.6\%).

However, Mortiz and Mortiz (2016) detected $S$. aureus as the main causative agent of mastitis. They reported that CNS were now considered as emerging agents. Mello et al. (2017,) when evaluating 181 Staphylococcus spp. isolates from cases of bovine subclinical mastitis in six Brazilian states, reported a higher occurrence of CNS (54.7\%) with S. chromogenes (14.7\%) being the main species isolated in this group and
S. aureus being the most isolated species in general. Additionally, the authors reported three species (S. warneri, S. simulans, and S. hominis), which were not found in our samples. This difference in the pattern of identification of isolates may be due to differences in the methodology used, considering that Mello et al. (2017) used biochemical tests.

In this study, 29 isolates sensitive to all active ingredients tested were detected: 21 S. chromogenes, three S. saprophyticus, three S. haemolyticus, and two S. hyicus. All 101 samples were sensitive to gentamicin, concurring with the results obtained by Schmidt Kock and Ehlers (2015) and Aslanta and Demir (2016).

Penicillin $G$ was the active ingredient with least effective action against the samples tested, with a sensitivity of $28.6 \%$ for CPS and $61.1 \%$ for CNS. This result was expected, as penicillin is widely used in the treatment of mastitis and the resistance of Staphylococcus $\mathrm{sp}$. to this antibiotic is commonly reported (Aslanta \& Demir, 2016; Papadopoulos. et al., 2018).

There was an association between the resistance profile of clindamycin ( $p<$ $0.05)$, streptomycin, and penicillin ( $p<0.01$ ) and the isolated staphylococcal species, with the bacteria belonging to the CPS and CNS groups having different behaviors against the tested antibiotics (Table 1). The percentage of resistance to streptomycin and penicillin $\mathrm{G}$ was higher among the coagulase-positive strains than among the negative strains. Conversely, the percentage of resistance to clindamycin was higher among the coagulase-negative strains compared to the positive strains. 
Table 1

Antimicrobial susceptibility profile of the coagulase-positive staphylococci and coagulase-negative staphylococci groups. There was an association between the resistance profile (sensitive, intermediary and resistant) and the type of Staphylococcus (coagulase- positive and coagulase-negative)

\begin{tabular}{|c|c|c|c|c|c|c|c|c|c|c|c|c|}
\hline \multirow{4}{*}{ Antimicrobial } & \multicolumn{12}{|c|}{ Antimicrobial susceptibility profile of the Staphylococcus spp. } \\
\hline & \multicolumn{4}{|c|}{ Sensitive } & \multicolumn{4}{|c|}{ Intermediary } & \multicolumn{4}{|c|}{ Resistant } \\
\hline & \multicolumn{2}{|c|}{$\mathrm{CP}$} & \multicolumn{2}{|c|}{$\mathrm{CN}$} & \multicolumn{2}{|c|}{$\mathrm{CP}$} & \multicolumn{2}{|c|}{$\mathrm{CN}$} & \multicolumn{2}{|c|}{$\mathrm{CP}$} & \multicolumn{2}{|c|}{$\mathrm{CN}$} \\
\hline & $\mathrm{N}$ & $\%$ & $\mathrm{~N}$ & $\%$ & $\mathrm{~N}$ & $\%$ & $\mathrm{~N}$ & $\%$ & $\mathrm{~N}$ & $\%$ & $\mathrm{~N}$ & $\%$ \\
\hline Ceftiofur & 24 & 85.7 & 53 & 73.6 & 1 & 3.6 & 2 & 2.8 & 3 & 10.7 & 17 & 23.6 \\
\hline Ciprofloxacin & 26 & 92.9 & 66 & 91.7 & 0 & 0.0 & 0 & 0.0 & 2 & 7.1 & 6 & 8.3 \\
\hline Clindamycin & 26 & 92.9 & 51 & 70.8 & 1 & 3.6 & 2 & 2.8 & 1 & 3.6 & 19 & $26.4^{*}$ \\
\hline Chloramphenicol & 26 & 92.9 & 53 & 73.6 & 1 & 3.6 & 4 & 5.6 & 1 & 3.6 & 15 & 20.8 \\
\hline Enrofloxacin & 27 & 96.4 & 61 & 84.7 & 0 & 0.0 & 2 & 2.8 & 1 & 3.6 & 9 & 12.5 \\
\hline Erythromycin & 22 & 78.6 & 54 & 75.0 & 5 & 17.9 & 16 & 22.2 & 1 & 3.6 & 2 & 2.8 \\
\hline Streptomycin & 5 & 17.9 & 42 & 58.3 & 19 & 67.9 & 25 & 34.7 & 4 & 14.3 & 5 & $6.9^{* *}$ \\
\hline Gentamicin & 28 & 100.0 & 72 & 100.0 & 0 & 0.0 & 0 & 0.0 & 0 & 0.0 & 0 & 0.0 \\
\hline Linezolid & 27 & 96.4 & 62 & 86.1 & 0 & 0.0 & 0 & 0.0 & 1 & 3.6 & 10 & 13.9 \\
\hline Penicillin G & 8 & 28.6 & 44 & 61.1 & 0 & 0.0 & 0 & 0.0 & 20 & 71.4 & 28 & $38.9^{* *}$ \\
\hline Rifampicin & 25 & 89.3 & 59 & 81.9 & 0 & 0.0 & 0 & 0.0 & 3 & 10.7 & 13 & 18.1 \\
\hline Tetracycline & 23 & 82.1 & 61 & 84.7 & 1 & 3.6 & 5 & 6.9 & 4 & 14.3 & 6 & 8.3 \\
\hline Cefoxitin & 24 & 85.7 & 53 & 73.6 & 0 & 0.0 & 0 & 0.0 & 4 & 14.3 & 19 & 26.4 \\
\hline
\end{tabular}

CP-Coagulase-positive; $\mathrm{CN}$-Coagulase negative; ${ }^{*} \mathrm{p}<0,05 ;{ }^{* *} \mathrm{p}<0,01$.

Although $S$. aureus is among the most prevalent and pathogenic species (Aslanta \& Demir, 2016), isolates from the CNS lineage may show greater resistance to the total number of antimicrobial classes, as well as a high profile of resistance to multiple drugs (Schmidt et al., 2015; Casanova et al., 2016). In this study, the multidrug resistance profile was also higher among the CNS (17/19), with $S$. chromogenes being the predominant species (12/19).

S. chromogenes was the isolate with the highest resistance of the species, showing resistance to the nine antimicrobial classes and resistance to 12 of the 13 antimicrobials tested. S. chromogenes was sensitive only to gentamicin. The S. kloosii strain was the bacterium with the highest sensitivity profile, being resistant only to penicillin $G$ and being the only strain that did not show a multidrugresistant phenotypic profile.

In all, 19 samples (18.8\%) were considered as multiresistant strains (Table 2) for showing resistance to more than three classes of antimicrobials: twelve $S$. chromogenes, two S. epidermidis, one $S$. aureus, one S. haemolyticus, one S. hyicus, one S. xylosus, and one $S$ saprophyticus. All multiresistant strains showed resistance to penicillin $\mathrm{G}$ and none to gentamicin. 
Table 2

Staphylococcus spp. classified as multiresistant because they showed resistance to more than three classes of antimicrobials, with the respective antimicrobials to which each species showed a resistance profile and its classes

\begin{tabular}{|c|c|c|c|c|c|c|c|c|c|c|c|c|}
\hline \multirow{4}{*}{ Species } & \multicolumn{12}{|c|}{ Antimicrobial classes } \\
\hline & \multicolumn{3}{|c|}{ Beta-lactam } & Lin & $\mathrm{Ch}$ & \multirow{2}{*}{\multicolumn{3}{|c|}{$\begin{array}{l}\text { Quinolone Mac } \\
\text { Antimicrobials }\end{array}$}} & Aminogly & \multirow[t]{2}{*}{ Oxa } & \multirow[t]{2}{*}{ Rif } & \multirow[t]{2}{*}{ Tet } \\
\hline & & & & & & & & & & & & \\
\hline & Ceft. & Cefo. & Pen. & Cli. & Ch. & Enr. & Cip. & Ery. & Str. Gen. & Lin. & Rif. & Tet. \\
\hline S. chromogenes & $\mathrm{R}$ & $\mathrm{R}$ & $\mathrm{R}$ & $\mathrm{R}$ & $\mathrm{R}$ & & & & & $\mathrm{R}$ & $\mathrm{R}$ & \\
\hline S. chromogenes & $\mathrm{R}$ & $\mathrm{R}$ & $\mathrm{R}$ & $\mathrm{R}$ & $\mathrm{R}$ & $\mathrm{R}$ & & & & & & \\
\hline S. chromogenes & & $\mathrm{R}$ & $\mathrm{R}$ & & & & $\mathrm{R}$ & & & $\mathrm{R}$ & $\mathrm{R}$ & \\
\hline S. chromogenes & $\mathrm{R}$ & & $\mathrm{R}$ & $\mathrm{R}$ & $\mathrm{R}$ & $\mathrm{R}$ & $\mathrm{R}$ & $\mathrm{R}$ & $\mathrm{R}$ & & $\mathrm{R}$ & $\mathrm{R}$ \\
\hline S. chromogenes & $\mathrm{R}$ & $\mathrm{R}$ & $\mathrm{R}$ & $\mathrm{R}$ & $\mathrm{R}$ & & & & & $\mathrm{R}$ & $\mathrm{R}$ & \\
\hline S. chromogenes & $\mathrm{R}$ & & $\mathrm{R}$ & $\mathrm{R}$ & $\mathrm{R}$ & $\mathrm{R}$ & $\mathrm{R}$ & & $\mathrm{R}$ & & & $\mathrm{R}$ \\
\hline S. chromogenes & $\mathrm{R}$ & & $\mathrm{R}$ & $\mathrm{R}$ & $\mathrm{R}$ & $\mathrm{R}$ & $\mathrm{R}$ & & & & & \\
\hline S. chromogenes & $\mathrm{R}$ & $\mathrm{R}$ & $\mathrm{R}$ & $\mathrm{R}$ & $\mathrm{R}$ & & & & & $\mathrm{R}$ & $\mathrm{R}$ & \\
\hline S. chromogenes & & $\mathrm{R}$ & $\mathrm{R}$ & & & $\mathrm{R}$ & $\mathrm{R}$ & $\mathrm{R}$ & $\mathrm{R}$ & & & $\mathrm{R}$ \\
\hline S. chromogenes & $\mathrm{R}$ & $\mathrm{R}$ & $\mathrm{R}$ & $\mathrm{R}$ & $\mathrm{R}$ & $\mathrm{R}$ & $\mathrm{R}$ & & & & & \\
\hline S. chromogenes & $\mathrm{R}$ & $\mathrm{R}$ & $\mathrm{R}$ & $\mathrm{R}$ & $\mathrm{R}$ & & & & $\mathrm{R}$ & $\mathrm{R}$ & $\mathrm{R}$ & \\
\hline S. chromogenes & $\mathrm{R}$ & $\mathrm{R}$ & $\mathrm{R}$ & $\mathrm{R}$ & $\mathrm{R}$ & $\mathrm{R}$ & $\mathrm{R}$ & & $\mathrm{R}$ & & & \\
\hline S. epidermidis & & $\mathrm{R}$ & $\mathrm{R}$ & $\mathrm{R}$ & $\mathrm{R}$ & & & & & $\mathrm{R}$ & $\mathrm{R}$ & \\
\hline S. epidermidis & $\mathrm{R}$ & $\mathrm{R}$ & $\mathrm{R}$ & $\mathrm{R}$ & $\mathrm{R}$ & & & & & $\mathrm{R}$ & $\mathrm{R}$ & \\
\hline S. saprophyticus & $\mathrm{R}$ & $\mathrm{R}$ & $\mathrm{R}$ & $\mathrm{R}$ & $\mathrm{R}$ & & & & & $\mathrm{R}$ & $\mathrm{R}$ & \\
\hline S. xylosus & & $\mathrm{R}$ & $\mathrm{R}$ & $\mathrm{R}$ & $\mathrm{R}$ & & & & & $\mathrm{R}$ & $\mathrm{R}$ & \\
\hline S. hyicus & $\mathrm{R}$ & $\mathrm{R}$ & $\mathrm{R}$ & $\mathrm{R}$ & $\mathrm{R}$ & & & & & $\mathrm{R}$ & $\mathrm{R}$ & \\
\hline S. haemolyticus & $\mathrm{R}$ & $\mathrm{R}$ & $\mathrm{R}$ & $\mathrm{R}$ & $\mathrm{R}$ & & & & & $\mathrm{R}$ & $\mathrm{R}$ & \\
\hline S. aureus & & & $\mathrm{R}$ & & & $\mathrm{R}$ & & & $\mathrm{R}$ & & & $\mathrm{R}$ \\
\hline
\end{tabular}

Lin- lincosamide, Ch- chloramphenicol, Mac- macrolides, Aminogly- aminoglycoside, Oxa- oxazolidinone, Rif- rifamycin, Tet- tetracycline, Ceft- ceftiofur, Cefo- cefoxitin, Cli- clindamycin, Enr- enrofloxacin, Cip- ciprofloxacin, Ery- erythromycin, Str- streptomycin, Gen- gentamicin, R- resistant.

Schmidt et al. (2015) found a lower rate of multidrug resistance. Later, Freitas et al. (2018) reported that out of the 30 Staphylococcus spp. isolates studied, three strains (10\%) were resistant to the 12 antibiotics tested, four strains (13.3\%) were resistant to 11 antibiotics, and 24 strains $(80 \%)$ to at least eight antibiotics. Despite the smaller number of isolates, the profile of multidrug resistance reported in their study was comparatively superior than the profile reported in the present study.

Freitas et al. (2018) concluded that multidrug resistance to antimicrobials occurs due to the extreme, empirical, or inadequate use of these drugs in the treatment and/or prophylaxis of diseases in bovine mammary glands. However, Casanova et al. (2016) 
suggested that resistance to multiple drugs in treatment may be associated with the persistence of agents in the herd, leading to cases of chronic infection and predisposing to further infection.

The isolates were examined by $D$ test and no induced resistance to clindamycin was observed. Cefoxitin, which is the in vitro surrogate for examining the phenotypic susceptibility of isolates to methicillin (CLSI, 2018), was used to detect MRS (methicillinresistant Staphylococcus), and altogether $77.2 \%$ of the isolates were sensitive to this antibiotic. Although the incidence of MRS is reported as low, this group should not be neglected, as MRS strains are resistant to virtually all beta-lactam antimicrobial drugs available (Papadopoulos et al., 2018).

The analyzed farms included small farmers, with low production and technological level, with little to no veterinary care. In all farms, milking was carried out when the calf was present with its mother (100\%). Altogether, only $10 \%$ of the farms used the CMT and wired cup test. None of them performed post-dipping, and only $10 \%$ performed pre-dipping. Less than half of them (45\%) cleaned the teats. Those who sanitized them, used only water to clean.

Only one farm reported that the teats were not dried after being sanitized. Among those who dried the teats after washing, $57.1 \%$ used cloth and $42.9 \%$ used paper towels. Milking was done by hand in $75 \%$ of the farms and $25 \%$ of the farms had a milking machine/mechanical milking.

Four farmers segregated mastitic cows at the time of milking. No farms used intensive farming, and one farm had no access to electricity. Only one farm did not have a corral and out of the farms that had corral, $60 \%$ cleaned it daily, by just scraping and washing with water. Only one farm used disinfectant in the daily cleaning of the corral.

The probability of finding animals affected by subclinical mastitis was higher in cows raised in a semi-confined system ( $p=0.008$ ) and in corrals without water for cleaning ( $p=0.029$ ). Oliveira (2015) reported that extensive grazing-based systems tend to spend less with mastitis cases than intensive systems. This is correlated with the dispersion of animals in the pasture, which allows for less contact between them and consequently, lower chances of transmitting diseases.

It was not possible to correlate the risk factors with the probability of finding CNS. As for CPS, manual milking $(p=0.006)$ and the absence of segregation of mastitic cows at the time of milking ( $p=0.013$ ) were identified as risk factors for subclinical mastitis. This may have occurred because $S$. aureus, which is the most prominent species among CPS, is considered the main pathogen responsible for contagious mastitis, in addition to occurring in the microbiota of the milker and teat epidermis. It is also important to note that infected cows act as reservoirs for the pathogen (Mesquita, 2017), being able to transmit the disease if they are milked before healthy animals during the milking process.

The most expressive result regarding antibiotic resistance was the greater incidence of multiresistant strains in corrals with no water for cleaning ( $p=0.032$ ). Although not significant, the absence of segregation of mastitic cows at the time of milking $(p=0.059)$ was another risk factor, which warrants further investigation. 
According to Mesquita (2017), the implementation of pre-dipping and the segregation of animals at the time of milking reduces the risks of high somatic cell count, which is an excellent indicator of mammary gland health. Moreover, cleaning and sanitizing utensils used for milking has a marked impact on the total bacterial count, thus characterizing them as preventive factors.

Therefore, water should be available during the entire milking process in the corral for cleaning. Oliveira (2015) highlights the importance of cleaning the cow's teats, the milker's hands, and inputs before the milking process. Not surprisingly, SantmanBerends, Swinkels, Lam, Keurentjes and Schaik (2016) noted that frequent cleaning of the premises floor was associated with fewer cases of mastitis, as better general hygiene is associated with lower chances of harboring any bacteria.

The segregation of cows at the time of milking works as a preventive factor, as it aims to prevent the transmission of microorganisms from infected animals to non-infected animals. Therefore, the absence of this measure can facilitate the transmission and spread of agents with multidrug resistance genes, which may have been selected, given the indiscriminate use of antimicrobials in farms lacking management and technical support.

This study provides information on the diversity of Staphylococcus spp. found in dairy herds in Acre, indicating the predominance of $S$. chromogenes and the circulation of multidrug resistance genes among the isolated species. Therefore, important data on the persistence of the disease in Acre were generated by studying mastitis in dairy herds and identifying the causative pathogens, their resistance profile, and associated risk factors. This facilitates the implementation of more effective control measures in a region composed largely of small farmers.

\section{Acknowledgments}

We would like to thank the Laboratory of Investigation in Medical Microbiology, Institute of Microbiology, Paulo Góes of Federal University of Rio de Janeiro, Brazil, for their contribution to the processing of samples in this study. Project was funded and supported with resources from the Public Notice 03/2016 FAPAC-CNPq, from the Primeiros Projetos Program, granted to Dr. Luciana dos Santos Medeiros.

\section{References}

Aslanta, O., \& Demir, C. (2016). Investigation of the antibiotic resistance and biofilmforming ability of Staphylococcus aureus from subclinical bovine mastitis cases. Journal of Dairy Science, 99(11), 86078613. doi: 10.3168/jds.2016-11310

Casanova, V. P., Appio, J., Kohl, E., Michaelsen, T. R., Paim, S. D., Brunetto, T. R. Girardini, L. (2016). Bovine mastitis: prevalence and antimicrobial susceptibility profile and detection of genes associated with biofilm formation in Staphylococcus aureus. Semina: Ciências Agrárias, 37(3), 13691378. doi: 10.5433/1679-0359.2016v37 n3p1369

Clinical \& Laboratory Standards Institute (2018). Performance standards for antimicrobial disk susceptibility tests. Wayne: West Valley Road. 
Freitas, C. H., Mendes, J. F., Villarreala, P. V., Santos, P. R., Gonçalves, C. L., Gindonis, V., Rantala, M. (2018). Occurrence and characterization of methicillinresistant staphylococci from bovine mastitis milk samples in Finland. Acta Veterinaria Scandinavica, 55(1), 61. doi: 10.1186/1751-0147-55-61

Ganda, E. K., Bisinotto, R. S., Decter, D. H., \& Bicalho, R. C. (2016). Evaluation of an on-farm culture system (accumast) for fast identification of milk pathogens associated with clinical mastitis in dairy cows. PLoS One, 11(5), 1-16. doi: 10.1371/ journal.pone.0155314.

Israel, L. F. S., Rabello, R. F., Domingos, S. C. B., \& Medeiros, L. S. (2018). Biofilm production by Staphylococcus chromogenes isolated from milk samples from bovine with mastitis. Arquivo Brasileiro de Medicina Veterinaria e Zootecnia, 70(6), 1943-1949. doi: 10.1590/1678-41629866

Mello, P. L., Pinheiro, L., Martins, L. de A., Brito, M. A. V. P., Cunha, R. de S., \& Cunha, M. de L. R. de S. (2017). Short communication: $\beta$-Lactam resistance and vancomycin heteroresistance in Staphylococcus spp. isolated from bovine subclinical mastitis. Journal of Dairy Science, 100(8), 65676571. doi: 10.3168/jds.2016-12329

Mesquita, A. A. (2017). Impacto da mastite bovina por Sthapylococcus aureus e Streptococcus agalactiae. Tese de mestrado, Universidade Federal de Lavras. Lavras, MG, Brasil. Recuperado de http://repositorio.ufla.br/jspui/ bitstream/1/28358/2/TESE_Impacto $\% 20$ da\%20Mastite\%20bovina\%20por\%20 Sthapylococcus $\% 20$ aureus $\% 20$ e 20 Streptococcus\%20agalactiae.pdf
Moritz, F., \& Moritz, C. M. F. (2016). Resistência aos antimicrobianos em Staphylococcus spp. associados à mastite bovina. Revista de Ciência Veterinária e Saúde Pública, 3(2), 132-136. doi: 10.4025/revcivet.v3i2. 34435

National Mastitis Council (2004). Procedures for collecting milk samples. Recuperado de https://www.nmconline.org/nmcprotocols-guidelines-and-procedures/.

Oliveira, C. S. F. (2015). Análise epidemiológica e bioeconômica da mastite bovina em rebanhos brasileiros. Tese de doutorado, Universidade Federal de Minas Gerais. Belo Horizonte, MG, Brasil. Recuperado de https://repositorio.ufmg. br/bitstream/1843/BUBD-A5GMBM/1/ texto_tese_final__camila_stefanie_ fonseca_de_oliveira.pdf

Papadopoulos, P., Papadopoulos, T., Angelidis, A. S., Boukouvala, E., Zdragas, A., Papa, A.Sergelidis, D. (2018). Prevalence of Staphylococcus aureus and of methicillin-resistant $S$. aureus (MRSA) along the production chain of dairy products in north-western Greece. Food Microbiology, 69,43-50. doi: 10.1016/j. fm.2017.07.016

Queiroz, A. M., \& Souza, L. G. S. (2021). Análise da produção de leite de vaca no Estado do Acre. Scientia Naturalis, 3(1), 97-104.

Sampaio, I. B. M. (1998). Estatística aplicada a experimentação animal. Belo Horizonte, MG, Brasil.

Santman-Berends, I. M. G. A., Swinkels, J. M., Lam, T. J. G. M., Keurentjes, J., \& Schaik, G. van. (2016). Evaluation of udder health parameters and risk factors for clinical mastitis in Dutch dairy herds in the context of a restricted antimicrobial usage policy. 
Journal of Dairy Science, 99(4), 29302939. doi: 10.3168/jds.2015-10398.

Schmidt, T., Kock, M., \& Ehlers, M. (2015). Diversity and antimicrobial susceptibility profiling of staphylococci isolated from bovine mastitis cases and close human contacts. Journal of Dairy Science, 98(9), 6256-6269. doi: 10.3168/jds.2015-9715 